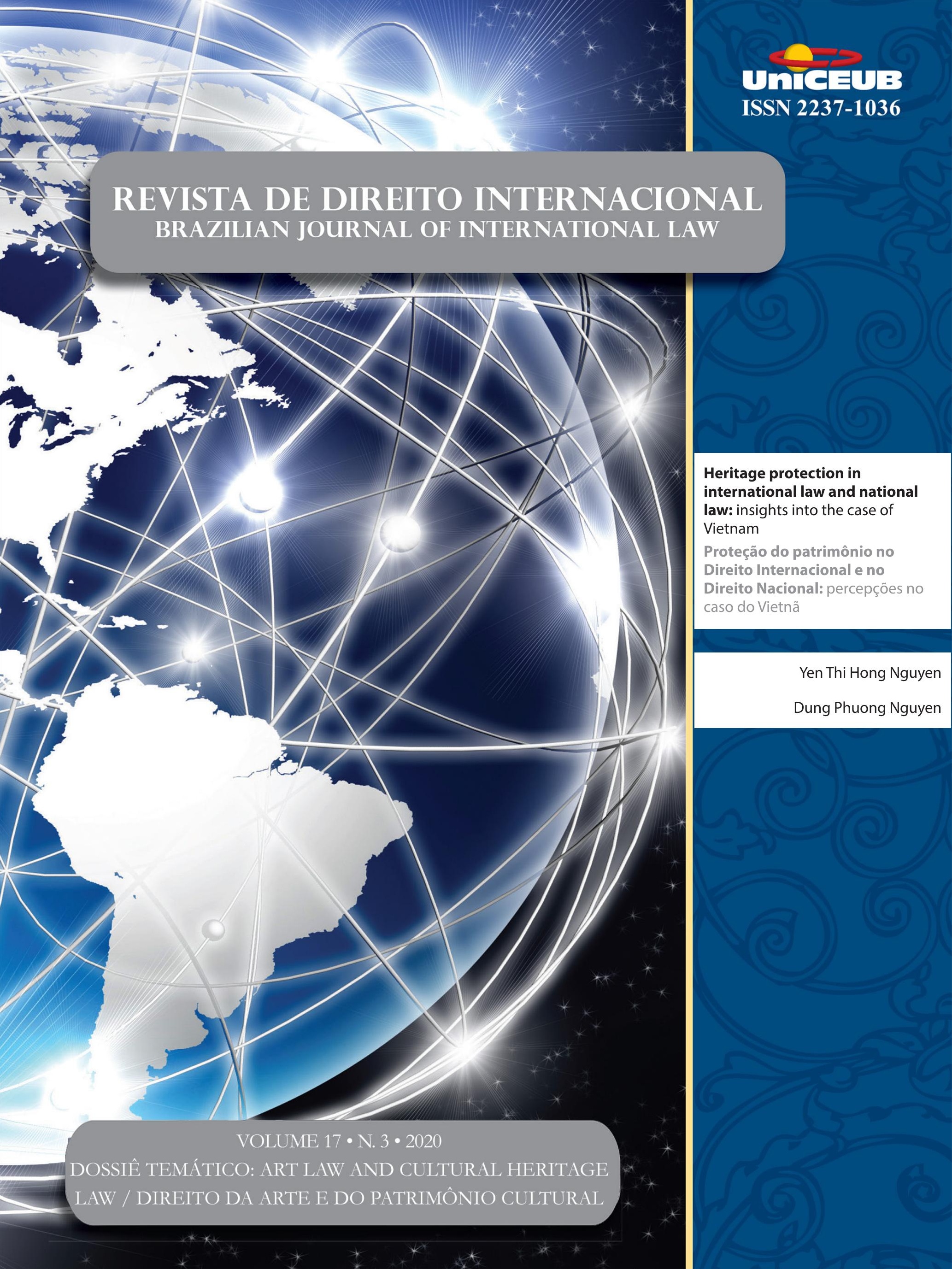




\section{Sumário}

EDITORIAL .20

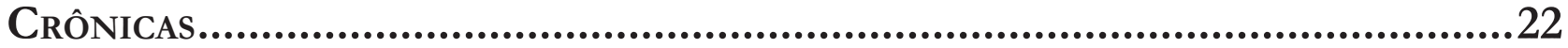

O COSTUME INTERNACIONAL COMO REFORÇO DA OBJEÇÃO BRASILEIRA À CLÁUSULA DO TRATAMENTO JUSTO E EQUITATIVO .24

Leonardo Vieira Arruda Achtschin

O PROCESSO LEGISLATIVO COMO GARANTIA PARA A OBTENÇÃo DO CONSENTIMENTO PRÉVIO DAS COMUnidades quilombolas de AlCÂNTARa

Gabriel de Oliveira Borba

Dossiê temático: Art Law and Cultural Heritage law / Direito da Arte e do Patrimônio cultural - Panorama Geral

Peoples' heritage or States' heritage? sovereignty in the UNESCO mechanism for THE SAFEGUARDING OF INTANGIBLE CULTURAL HERITAGE.

Aliki Gkana

The IMPACT OF THE UNESCO AND UNIDROIT CONVENTIONS AND THE EU DIRECTIVES ON THE INTERNATIONAL ART MARKET: AN ANALYSIS FIFTY YEARS AFTER THE INTRODUCTION OF THE OBLIGATION TO RETURN STOLEN OR ILLEGALLY EXPORTED CULTURAL GOODS 61

Geo Magri

Três pautas em destaque na agenda de diversidade Cultural da Unesco: Ambiente digiTAL, TRATAMENTO PREFERENCIAL E PARTICIPAÇÃO DA SOCIEDADE CIVIL............................76

Danilo Júnior de Oliveira, Maria Carolina Vasconcelos Oliveira e Ana Paula do Val

A 100 YEARS INSTITUTIONALIZED CULTURAL HERITAGE PROTECTION: FROM THE INSTITUTIONALIZED INTERNATIONAL COOPÉRATION INTELLECTUELLE TO THE HUMAN RIGHT TO CULTURAL HERITAGE

Lando Kirchmair 


\section{Aspectos Metodológicos do Direito da Arte e do Patrimônio}

Cultural

A proteção do PATrimônio CULTURAL EM NOVAS PERSPECTIVAS: ESTUdo COMPARAdo ENTRE A Kulturgutschutzgesetz e a Holocaust Expropriated Art Recovery Act of 2016.....111 Ardyllis Alves Soares

ArT-RELATED DispUTES AND ADR METHODS 127 Maria Beatrice Deli e Veronica Proietti

Due Diligence in Art Law and Cultural Heritage Law 150 Lisiane Feiten Wingert Ody

The Reception of Droit de Suite in International Law: Diagnosis and Remedy .... 170 Mickael R. Viglino

Direito da Arte e do Patrimônio Cultural: do Regional ao Local ....... 188

Câmara Cascudo e o legal Design - A Visualidade do Direito entre Provincianismo e GlobalizaÇão 190 Marcilio Toscano Franca Filho

A política da União Europeia no turismo: O turismo cultural e a sustentabilidade do PATRIMONNIO INDUSTRIAL PARA INTEGRAÇÃO DO BLOCO EUROPEU

Maraluce Maria Custódio e Fernando Barotti dos Santos

Diálogo entre la Corte Interamericana de Derechos Humanos y el Tribunal Europeo de Derechos Humanos en torno al Derecho humano a la identidad cultural..223 Juan Jorge Faundes

Digital ART AND THE BELT AND ROAD INITIATIVE: CHALLENGES AND OPPORTUNITIES 257 Dan Wei e Ângelo Rafael

Policing heritage crime in Latin America. .275 Naomi Oosterman e Donna Yates 
The principles of Cultural Heritage Law based on the Polish Law as an example.292 Małgorzata Joanna Węgrzak e Kamil Zeidler

Heritage Protection in INTERNATIONAL LAw AND NATIONAL LAW: INSIGHTS INTO THE CASE OF VIETNAM

Yen Thi Hong Nguyen e Dung Phuong Nguyen

THE APPROPRIATION OF THE CARIOCA INTANGIBLE CULTURAL HERITAGE BY AN ENTREPRENEURIAL LOGIC

Mário Ferreira de Pragmácio Telles

A Propósito del CARÁcter UNIVERSAL DEL aCCESO A LA CULTURA EN INTERNET: UN ANÁlisis DESDE EL PRISMA INTERNACIONAL Y LA EXPERIENCIA DEL ORDENAMIENTO JURÍDICO CUBANO 344 Janny Carrasco Medina

Direito Humanitário e Arte

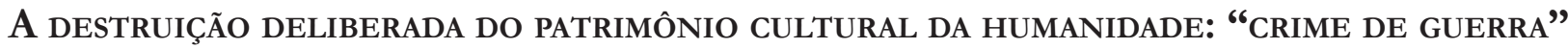
OU "CRIME CONTRA A HUMANIDADE"? Juliette Robichez

Protection OF CULTURAL PROPERTY UNDER INTERNATIONAL HUMANITARIAN LAW: EMERGING TRENDS

Niteesh Kumar Upadhyay e Mahak Rathee

Direito do Mar/Marítimo e Arte.

The underwater Cultural heritage Regime: SOME PROBlems AND POSSible SOlutions. 412 Elina Moustaira

El ROL DEL DERECHO EN LA CONSTRUCCIÓN DEL PATRIMONIO CULTURAL SUBACUÁTICO: APRECiaciones a partirdel estudio del CASo de la Corbeta Inglesa SwifT en Argentina .. 424 Norma Elizabeth Levrand e Nadia Bressan Bernhardt 
INDIGENOUS REFUGEES AND CULTURAL EROSION: POSSIBILITIES AND LIMITS OF INTERNATIONAL REFUGEE AND INDIGENOUS PEOPLES LAW IN THE PROTECTION OF INDIGENOUS CULTURAL EXPRESSIONS RELATED TO TRADITIONAL LAND AND NATIVE LANGUAGE. .440 Rickson Rios Figueira

O RETRATO DE EDMOND BELAMY E A INTERFACE ENTRE ARTE E INTELIGENCIA ARTIFICIAL: POR UMA NOVA DEFINIÇÃo DE AUTORIA E DIREITOS DE PROPRIEDADE INTELECTUAL

Marla Meneses do Amaral Leite Mangiolardo, Patrícia Silva de Almeida e Jonathan Barros Vita

Argumentative aspects of Declaration on the Importance and Value of Universal Museums (2002) 479

Agnieszka Plata

A DestinaÇão dos bens CUlturais EM PROCESSOS PENAIS: A ARTE COMO REPARAÇÃo COLETIVA 488

Inês Virgínia Prado Soares e Otavio Venturini

A Justiça de Pieter Bruegel: direito, violência e a venda nos (nossos) olhos. .501 Rafael Lazzarotto Simioni e Cícero Krupp

Artigos Sobre outros temas

DEVERES INTERNACIONAIS E OBRIGAÇÕES SOCIOAMBIENTAIS PARA EMPRESAS MULTI E TRANSNACIONAIS

Luísa Cortat Simonetti Gonçalves e Adriano Sant'Ana Pedra

Maternidade por substituição: perspectivas da ConferênCia da Haia e suas potenciais INFLUÊNCIAS NO REGRAMENTO BRASILEIRO

Tatiana de A. F. R. Cardoso Squeff e Fernanda Rezende Martins

EL (LARGO) CAMINO DE RECONOCIMIENTO Y EJECUCIÓN DE LAUDOS ARBITRALES DE INVERSIÓN

Thiago Paluma, Ivette Esis e Gabriel Briceño 
A INTERPRETAÇÃo EVOLUTIVA DA CONVENÇÃo AMERICANA SOBRE DiREITOS HUMANOS: UMA REVISÃO DOCUMENTAL DO PERÍODO 1988-2018

Breno Baía Magalhães

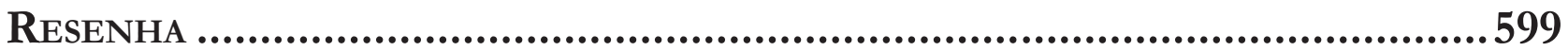

Autonomous Weapons Systems and InTERnATIONAL LAw: A STUDY ON HUMAN-MACHINE INTERACTIONS IN ETHICALLY AND LEGALLY SENSITIVE DOMAINS

Aziz Tuffi Saliba e Lutiana Valadares Fernandes Barbosa 


\title{
Heritage protection in international law and national law: insights into the case of Vietnam*
}

\author{
Proteção do patrimônio no Direito \\ Internacional e no Direito Nacional: \\ percepções no caso do Vietnã
}

\author{
Yen Thi Hong Nguyen** \\ Dung Phuong Nguyen***
}

\begin{abstract}
Vietnam's cultural heritage is the precious property of the Vietnamese people, forged through thousands of years of building and defending the country. Despite experiencing numerous historical events, losses and damage caused by wars and severe natural disasters, Vietnam's treasure of cultural heritage is plentiful and diverse, significantly contributing to the formation of the personality of Vietnamese people and the development of the country. Recognising the importance of heritage preservation, Vietnam officially became a member of core international conventions under the auspices of UNESCO with the desire to strengthen and improve the national legislative system to better protect cultural heritage exposed to risks of degradation and deterioration. To evaluate the implementation of legal instruments on heritage protection of UNESCO, the authors will analyse the international and Vietnamese legal framework on heritage protection. The paper then will provide insights into the current practice of heritage preservation and challenges that the Vietnamese government has been facing in the process of balancing heritage preservation and economic development. Based on the analyses and evaluations in the preceding parts, the paper will discuss and propose solutions to reinforce the legal protection for heritage in Vietnam in the future.
\end{abstract}

Keywords: Heritage Protection. Heritage Safeguarding. International Cultural Heritage Law. Vietnamese Cultural Heritage Law.

* Recebido em 30/09/2020 Aprovado em 25/03/2021

** The Head of Public International Law Division, Hanoi Law University

E-mail: Hongyennguyen.hlu@gmail.com

*** Lawyer

E-mail: p.d.nguyen1812@gmail.com

\section{Resumo}

O objetivo principal deste artigo é analisar a proteção do patrimônio sob o direito internacional e o direito vietnamita. A Organização das Nações Unidas para a Educação, a Ciência e a Cultura (UNESCO) é a principal agência encarregada de salvaguardar a cultura da humanidade e unificar as nações para cooperar entre si para alcançar o alcance da proteção do patrimônio. Os instrumentos internacionais da UNESCO amplamente reconhecidos fornecem uma estrutura para a lei do patrimônio cultural internacional. À luz da legislação internacional existente sobre proteção do patrimônio, o artigo fornece informações sobre a legislação vietnamita sobre o mesmo 
assunto. $\mathrm{O}$ artigo também aponta as falhas existentes no sistema jurídico de patrimônio cultural do Vietnã. Embora o Governo do Vietnã tenha adotado uma abordagem holística na busca da proteção e promoção do patrimônio cultural e dos valores tradicionais, a falta de cuidado e o apoio insuficiente às comunidades e artistas causaram desafios e dificuldades ao Governo vietnamita e às necessidades de reforma em os processos de formulação e aplicação da lei para restabelecer o equilíbrio entre a proteção do patrimônio e as demandas de desenvolvimento econômico.

Palavras-chave: Proteção do patrimônio, salvaguarda do patrimônio, Direito Internacional do Patrimônio Cultural, Direito do Patrimônio Cultural vietnamita

\section{Introduction}

Farida Shaheed - the former UN High Commission for Human Rights Independent Expert in 2009 - 2012 and Special Rapporteur in the Field of Cultural Rights in $2012-2015$, in her speech, pointed to the interconnection between cultural heritage and human culture:

Cultural heritage is linked to human dignity and identity. Accessing and enjoying cultural heritage is an important feature of being a member of a community, a citizen, and, more widely, a member of society. ${ }^{1}$

Along with the enjoyment of cultural heritage, there is the need for obligations to protect and safeguard valuable heritage properties. The advent of the United Nations Educational, Scientific and Cultural Organisation (UNESCO) indicates the international community's attempt in safeguarding cultural heritage throughout its key conventions in this regard.

Vietnam's heritage is the precious property of local communities in Vietnam, forged through a thousand years of building and defending the country. Heritage is a symbol of longevity and the bridge between the past, present and future of the people. This enormous treasure of heritage contributes to the richness and diversity in Vietnamese culture and acts as a critical component that drives economic growth in its socio-econo-

HUMAN RIGHTS COUNCIL. Report of the Independent Expert in the Field of Cultural Rights, Farida Shabeed. No. A/HRC/17/38. 21st Mar. 2011. Available at: https://undocs.org/pdf?symbol=en/A/ HRC/17/38. para. 2. mic development. Over the past years, cultural heritage has been identified, preserved and promoted, playing a significant part in the education of history, nurturing fine traditions, building and promoting the image of the country, disseminating the historical, cultural and scientific values and beauty of Vietnam's heritage to the world. In terms of socio-economic development, several heritage sites have become cultural and tourist attractions, acting as both a powerful motivator and target for developing tourism into a key economic sector, gradually changing the economic structures of the localities at which the heritages are located, and bringing practical and sustainable benefits to the local communities. $^{2}$

Vietnam's incumbent Prime Minister - Nguyen Xuan Phuc said that "Heritage is a valuable endowment of nature or essence of our predecessors' creativity, passed down through generation after generation. We should understand that anything can be built, produced, and created, but heritage cannot". ${ }^{3}$ Vietnam has numerous heritage sites and intangible heritage elements recognised by UNESCO. This has played an important role in introducing Vietnamese culture to the international community, creating a "global brand" and generating vast incomes from tourism, as well as improving the life quality of local people and communities in the localities where heritage sites are located or where there are heritage elements. However, the foremost thing that UNESCO has brought to the State is the awareness and the building of respect across the whole society, from country leaders to ordinary citizens. Hence, heritage preservation is crucial and necessary for developing and enriching the country. In addition, the Prime Minister highlighted that heritage preservation is not only the State's responsibility but also the shared task of all people and communities. ${ }^{4}$

2 COMMUNIST PARTY OF VIETNAM. Bảo vệ và phát huy giá trị di săn văn hóa Việt nam vì sự phát triên bền vũng. [Protection and promotion of the values of Vietnamese cultural heritage for the aim of sustainable development]. Available at: http://dangcongsan.vn/ tu-tuong-van-hoa/bao-ve-va-phat-huy-gia-tri-di-san-van-hoa-vietnam-vi-su-phat-trien-ben-vung-491901.html.

3 VOV5. PM calls for joint efforts to preserve cultural heritage. Available at: https://vov.vn/en/culture/pm-calls-for-joint-efforts-to-preserve-cultural-heritage-381480.vov.

4 GOVERNMENT PORTAL OF THE SOCIALIST OF VIETNAM. Giới thiệu chung về Tổ chức Giáo dục, Khoa học và Văn bóa của Liên Hợp Quốc (UNESCO). [An overview of the United Nations Educational, Scientific and Cultural Organization (UNESCO)]. Available at: http://www2.chinhphu.vn/portal/page/portal/chinhphu/NuocCHXHCNVietNam/ChiTietVe'ToChucQuocTe?diplom 
Realising the importance of heritage preservation, Vietnam participated in and officially became a member of UNESCO's core conventions regulating the same subject matter with the desire to strengthen and improve the national legislative system to better protect heritage at risk of degradation and deterioration. After more than 30 years of participating in and implementing the 1972 World Heritage Convention, aside from achieving some positives, there have been some shortcomings. Social awareness of heritage values is not widespread or comprehensive. Legal compliance in heritage protection is poor. Although a set of laws and regulations on heritage preservation have been issued, the implementation and enforcement of such are weak. The relationship which exists between heritage preservation and the local community has not been well-maintained.

From that practice, in order to assess concretely the implementation of UNESCO's international tools for the protection of cultural heritage and challenges that Vietnam has been facing in heritage protection. Through analyses, summaries and comparisons, in this paper, the authors will: (i) analyse the international and Vietnamese legal framework on heritage protection; (ii) provide insights into the current practice of heritage preservation and challenges that the Vietnamese government has been facing in the process of balancing heritage preservation and economic development; (iii) discuss and propose solutions to reinforce the legal protection for heritage in Vietnam in the future.

\section{International Legal Framework on Heritage Protection}

Heritage protection is one of the focuses of the international community to preserve humankind values to the next generations. With the aim "to achieve international co-operation in solving international problems of an economic, social, cultural, or humanitarian character", 5 the United Nations recognises that heritage protection is one of the crucial common missions of the international community. UNESCO plays a leading role in "assuring the conservation and protection of the world's inheritance of books, works of art and monuments of history and science, and recommending

acyOrgId $=126$.

UNITED NATIONS. Charter of the United Nations. 1945. art 1.3. to the nations concerned the necessary international conventions". ${ }^{6}$ Under the auspices of UNESCO, a statutory framework for the protection of world heritage has been comprehensively developed. In this part, the authors will concentrate on analysing the core UNESCO Conventions which are most widely accepted in the field of heritage protection.

\subsection{Convention on the Means of Prohibiting and Preventing the Illicit Import, Export and Transfer of Ownership of Cultural Property (1970) ("1970 UNESCO Convention")}

The 1970 UNESCO Convention adopted in the $16^{\text {th }}$ General Conference of UNESCO on 14 November 1970 combats the unlawful import, export and transfer of ownership of culture property that is believed to be "one of the main causes of the impoverishment of the cultural heritage of the countries of origin of such property". 7

According to Toshiyuki Kono and Stefan Wrbka, in light of the provisions provided in the 1970 UNESCO Convention, origin nations of cultural property lie at the heart of the protection and preservation of cultural property, whereas cultural exchange is auxiliary. ${ }^{8}$ The authors additionally analysed principal constituent parts of the 1970 UNESCO Convention that tackle "illicit import, export and transfer of ownership of cultural property". The first protective mechanism is the prevention of such illegal conduct. States Parties are the main actors taking responsibility for setting forth "national services" encompassing numerous preventative measures circumventing illicit conduct, including the establishment of national inventories of protected property, formulation of draft laws and regulations aimed at protecting cultural property and addressing illicit conduct, ${ }^{9}$ administrative management in the export of cultural property, ${ }^{10}$ and imposition of sanctions. ${ }^{11}$

However, the language under the 1970 UNESCO Convention is not explicit enough to determine the

UNESCO. UNESCO Constitution. 1945. art 2(c).

1970 UNESCO Convention art 2.1

8 KONO, Toshiyuki; WRBKA, Stefan. General report: protection and preservation of cultural heritage in the impact of uniform laws on the protection of cultural heritage and the preservation of cultural heritage in the 21st century. Leiden: Brill; Nijhoff, 2010. p. 35.

1970 UNESCO Convention art 5.

$10 \quad 1970$ UNESCO Convention art 6.

$11 \quad 1970$ UNESCO Convention art 8. 
subjects to which the 1970 UNESCO Convention is addressed. Considering the governing scope of the 1970 UNESCO Convention, this Convention directly applies to States Parties and their agencies only, not private actors that are not controlled by States. The 1970 UNESCO Convention requires States Parties to avert the acquisition of illegally exported cultural property by museums and similar institutions within their territories in congruence with national legislation. ${ }^{12}$ This poses ambiguity in determining "what kind of museums and institutions are affected", and whether this merely applies to those "whose acquisition policies are controlled by the State". ${ }^{13}$

The other safeguarding mechanism of the 1970 UNESCO Convention is the return of illegally exported or imported cultural property on the basis of transnational cooperation. The State in which the cultural property is unlawfully acquired has the responsibility to restitute such cultural property to the source State Party at its request. Nevertheless, the protection is only offered to

cultural property stolen from a museum or a religious or secular public monument or similar institution in another State Party to this Convention after the entry into force of this Convention for the States concerned, provided that such property is documented as appertaining to the inventory of that institution. ${ }^{14}$

In other words, cultural property stolen from private homes is not included under the protective regime of the 1970 UNESCO Convention. ${ }^{15}$

The State of origin, upon the request for restitution, is liable for "just compensation to an innocent purchaser or to a person who has valid title to that property". ${ }^{16}$ The vagueness of the wording has received a lot of criticism. At this juncture, Patrick. J. O'Keefe, in his commentary on the 1970 UNESCO Convention, clarified that the Convention's language is indistinct as it is impossible to sharply define a one-size-fits-all approach

\footnotetext{
121970 UNESCO Convention art 7(a).

13 KONO, Toshiyuki; WRBKA, Stefan. General report: protection and preservation of cultural heritage in the impact of uniform laws on the protection of cultural heritage and the preservation of cultural heritage in the 21st century. Leiden: Brill; Nijhoff, 2010. p. 39. 141970 UNESCO Convention art 7(b)(i).

15 KONO, Toshiyuki; WRBKA, Stefan. General report: protection and preservation of cultural heritage in the impact of uniform laws on the protection of cultural heritage and the preservation of cultural heritage in the 21st century. Leiden: Brill; Nijhoff, 2010. p. 40.

161970 UNESCO Convention art 7(b)(ii).
}

of compensation payments in the context of the broad application of the Convention to all States Parties whose legal systems vary in nature. He opined that compensation payment shall be subjected to the national laws and national courts of State Parties, who, at their discretion, shall determine the compensation amount which will not be limited to the originally paid prices. Likewise, regarding the term "innocent purchaser" or "a person who has valid title to that property", given the absence of clarification under the Convention, this means that States Parties are vested to define bona fide purchase or owner of cultural property in national laws. ${ }^{17}$

International cooperation in fighting illegal purchase or transfer of cultural property is another core component of the 1970 UNESCO Convention. ${ }^{18}$ Toshiyuki Kono and Stefan Wrbka pointed to the insufficiency of national laws in tackling the illicit import and export of cultural property and highlighted the importance of international cooperation through bilateral or multilateral treaties which will offer more protective mechanisms to cultural property. ${ }^{19}$

The application of the 1970 UNESCO Convention exhibits a serious defect in that it cannot be applied expost facto due to an absence of an applicable timeframe. This has left cultural property illicitly imported or exported before the effective date of the Convention unprotected. To deal with this imperfection, UNESCO, through adopting Resolution $20 \mathrm{C} 4 / 7.6 / 5$ of the $20^{\text {th }}$ session of the Conference General of UNESCO, established the Intergovernmental Committee for Promoting the Return of Cultural Property to its Countries of Origin or its Restitution in Case of Illicit Appropriation ("ICPRCP") consisting of 22 Member States of UNESCO. The ICPRCP is in a permanent state of providing consultancy to Member States and takes the leading role in the restitution of cultural property and reinforcing the implementation of the 1970 UNESCO Convention through its key task of encouraging cultural property protection. ${ }^{20}$ The founda17 O'KEEFE, Patrick J. Commentary on the 1970 UNESCO Conven-
tion. 2. ed. Builth Wells: The Institute of Art and Law, 2007. p. 65 ;
KONO, Toshiyuki; WRBKA, Stefan. General report: protection and
preservation of cultural heritage in the impact of uniform laws on
the protection of cultural heritage and the preservation of cultural
heritage in the 21 st century. Leiden: Brill; Nijhoff, 2010. p. 40.
$18 \quad 1970$ UNESCO Convention arts 9 and 15.
$19 \quad$ KONO, Toshiyuki; WRBKA, Stefan. General report: protection
and preservation of cultural heritage in the impact of uniform laws
on the protection of cultural heritage and the preservation of cul-
tural heritage in the 21 st century. Leiden: Brill; Nijhoff, 2010. p. 41.
20 UNESCO. Statutes of the Intergovernmental Committee for Promoting the 
tion of the ICPRCP is an effective solution to fulfil the existing gap in the returning of cultural property arising from the implementation of the 1970 UNESCO Convention in practice. ${ }^{21}$ UNESCO further set up the Fund of the Intergovernmental Committee for Promoting the Return of Cultural Property to its Countries of Origin or its Restitution in case of Illicit Appropriation calling for and collecting voluntary payments from States and private sectors to provide financial support to the operation of the ICPRCP, particularly the processes of returning cultural property. ${ }^{22}$ According to Toshiyuki Kono and Stefan Wrbka, this is considered UNESCO's most strenuous effort through the application of the 1970 UNESCO Convention to assist poorer States in preserving and safeguarding their cultural property. ${ }^{23}$

\subsection{Convention Concerning the Protection of the World Cultural and Natural Heritage (1972) ("1972 World Heritage Convention")}

In 1972, the General Assembly adopted the Convention Concerning the Protection of the World Cultural and Natural Heritage ("1972 World Heritage Convention"), marking an important milestone on the long road to safeguard world heritage. According to UNESCO, the 1972 World Heritage Convention aims to offer protection to "certain places on Earth" that "are of outstanding universal value and should therefore form part of the common heritage of humankind". By ratifying this Convention, the States Parties "have become part of an international community, united in a common mission to identify and safeguard our world's most outstanding natural and cultural heritage" 24.25

Return of Cultural Property to its Countries of Origin or its Restitution in case of Illicit Appropriation. $20 \mathrm{C} /$ Resolution 4/7.6/5 of the 20th session of the General Conference of UNESCO. Paris, 24 Oct.-28 Nov. 1978. Available at: https://unesdoc.unesco.org/ark:/48223/pf0000145960.

${ }^{21}$ KONO, Toshiyuki; WRBKA, Stefan. General report: protection and preservation of cultural heritage in the impact of uniform laws on the protection of cultural heritage and the preservation of cultural heritage in the 21 st century. Leiden: Brill; Nijhoff, 2010. p. 36, 42-43.

22 UNESCO. General Conference Resolution 27. UNESCO 30th session. Paris, 26 Oct.-17 Nov. 1999. Available at: https://unesdoc.unesco.org/ark:/48223/pf0000118514.

23 KONO, Toshiyuki; WRBKA, Stefan. General report: protection and preservation of cultural heritage in the impact of uniform laws on the protection of cultural heritage and the preservation of cultural heritage in the 21st century. Leiden: Brill; Nijhoff, 2010. p. 43.

24 UNESCO. World Heritage Centre. What is the World Heritage Convention. Available at: https://whc.unesco.org/en/faq/21.

25 KONO, Toshiyuki; WRBKA, Stefan. General report: protection
While the 1970 UNESCO Convention focuses on protecting cultural property from illegal import or export, the 1972 World Heritage Convention's protective scope is more comprehensive as at that time the international community had been more aware of protecting heritage in the aftermath of the civil war periods and developments after the wars. ${ }^{26}$ Toshiyuki Kono and Stefan Wrbka offered their understanding of the protective regime under the 1972 World Heritage Convention. Specifically, in their General Report, the authors found that the 1972 World Heritage Convention created a hybrid of culture and nature which "did not seem to have much in common", and upgraded the safeguarding degree of cultural property to "world heritage". ${ }^{27}$

They additionally looked at the concepts of "cultural heritage" and "natural heritage" in the 1972 World Heritage Convention. From their perspective, it cannot be based on the description given in Articles 1 and 2 of the Convention only to define "cultural heritage" or "natural heritage" as the terms themselves "are not exclusive in the sense that they cover every possible facet of what can be called cultural heritage or natural heritage in a broad sense...neither do they refer to mere movable objects nor to mere intangible heritage". They pointed out that the terms retained strong links with the term "outstanding universal value" which has yet to be explained under the Convention despite being referred to. ${ }^{28}$

Under this Convention, an Intergovernmental Committee for the Protection of the Cultural and Natural Heritage of Outstanding Universal Value (the "World Heritage Committee") was established. ${ }^{29}$ The World Heritage Committee is vested with the authority to "define the criteria on the basis of which a property belongs to the cultural or natural heritage". This Committee

and preservation of cultural heritage in the impact of uniform laws on the protection of cultural heritage and the preservation of cultural heritage in the 21st century. Leiden: Brill; Nijhoff, 2010. p. 39.

26 KONO, Toshiyuki; WRBKA, Stefan. General report: protection and preservation of cultural heritage in the impact of uniform laws on the protection of cultural heritage and the preservation of cultural heritage in the 21st century. Leiden: Brill; Nijhoff, 2010. p. 44.

${ }_{27}$ KONO, Toshiyuki; WRBKA, Stefan. General report: protection and preservation of cultural heritage in the impact of uniform laws on the protection of cultural heritage and the preservation of cultural heritage in the 21st century. Leiden: Brill; Nijhoff, 2010. p. 45. 28 KONO, Toshiyuki; WRBKA, Stefan. General report: protection and preservation of cultural heritage in the impact of uniform laws on the protection of cultural heritage and the preservation of cultural heritage in the 21st century. Leiden: Brill; Nijhoff, 2010. p. 4647.

$29 \quad 1972$ World Heritage Convention art 8. 
forms the "World Heritage List" and "List of World Heritage in Danger" to determine and categorise properties by developing a series of criteria in the Operational Guidelines for the Implementation of the World Heritage Convention ${ }^{30} .{ }^{31}$ In the Operational Guidelines, the Committee clarified the term "outstanding universal value" as "cultural and/or natural significance which is so exceptional as to transcend national boundaries and to be of common importance for present and future generations of all humanity". ${ }^{32}$ The Committee has kept re-examining and reviewing the criteria for heritage determination and categorisation since they first adopted the WHC Operational Guidelines on 30 June 1977 to ensure the criteria keep pace with and reflect changes, developments and deal with disparities stemming from the implementation of the Convention. Toshiyuki Kono and Stefan Wrbka considered the revision of the WHC Operational Guidelines "an important tool for a flexible application of the fixed scaffolding provided by the Convention". Furthermore, the World Heritage Committee has attempted to redress the balance by "adopting a better-balanced system of incorporation and encouraging less-represented States Parties to contribute to the inscription process by providing more and above all more promising - nominations". ${ }^{33}$

However, the 1972 World Heritage Convention never attempts to develop one-size-fits-all legislation on heritage protection. In the form of an international treaty, the 1972 World Heritage Convention was formed on the basis of two pillars of the international legal system which are State sovereignty and equality. Moreover, like other treaties on heritage protection, it is dependent on States' commitments and co-operation amongst the States. At this point, Craig Forrest pointed to States' enjoyment of complete sovereignty:

Given that each State has absolute sovereignty over

30 UNESCO. World Heritage Committee. Operational Guidelines for the Implementation of the World Heritage Convention. WHC.19/01, 10 July 2019. ("the WHC Operational Guidelines").

311972 World Heritage Convention art 11; KONO, Toshiyuki; WRBKA, Stefan. General report: protection and preservation of cultural heritage in the impact of uniform laws on the protection of cultural heritage and the preservation of cultural heritage in the $21 \mathrm{st}$ century. Leiden: Brill; Nijhoff, 2010. p. 48.

32 WHC Operational Guidelines. para 49.

33 KONO, Toshiyuki; WRBKA, Stefan. General report: protection and preservation of cultural heritage in the impact of uniform laws on the protection of cultural heritage and the preservation of cultural heritage in the 21 st century. Leiden: Brill; Nijhoff, 2010. p. 4950 . its territory, it has absolute sovereignty over the cultural heritage found on that territory, and practically and, as a fundamental principle of international law, that State may regulate that heritage in any way it wishes. ${ }^{34}$

By setting forth a protective regime of heritage, it does not mean that the 1972 World Heritage Convention attempts to undermine the national sovereignty and States' rights to manage properties on their territories. When participating in the 1972 World Heritage Convention, "each State agrees that it will assume certain international obligations in regard to that cultural heritage and which will require it to act (or refrain from acting) in certain ways". ${ }^{35}$ In other words, it cannot be regarded as intervention of national sovereignty, if there is any interference from UNESCO or other States to protect a property found on the territory of a State in compliance with the 1972 World Heritage Convention where such State has taken part in the Convention. This is considered "a reflection of that State's sovereignty in entering into the conventional regime" and accordingly, "each State Party recognises that certain heritage situated in its territory is to be regarded as world heritage" and subjected to the protective regime under the Convention. ${ }^{36}$

As analysed above, States Parties are the main actors implementing the 1972 World Heritage Convention with dual duties of "taking every necessary step to guarantee the protection of World Heritage situated in the territories and protecting their national heritage in general on a national level". ${ }^{37}$ In particular, each State member shall take measures in formulating a complete list of heritage located in its territories by identifying the

34 FORREST, Craig. International law and the protection of cultural heritage. Routledge, 2010. p. 48.

35 FORREST, Craig. International law and the protection of cultural heritage. Routledge, 2010. p. 48; KONO, Toshiyuki; WRBKA, Stefan. General report: protection and preservation of cultural heritage in the impact of uniform laws on the protection of cultural heritage and the preservation of cultural heritage in the 21 st century. Leiden: Brill; Nijhoff, 2010. p. 51.

36 FORREST, Craig. International law and the protection of cultural heritage. Routledge, 2010. p. 48; KONO, Toshiyuki; WRBKA, Stefan. General report: protection and preservation of cultural heritage in the impact of uniform laws on the protection of cultural heritage and the preservation of cultural heritage in the 21 st century. Leiden: Brill; Nijhoff, 2010. p. 51.

371972 World Heritage Convention arts 4 and 5; KONO, Toshiyuki; WRBKA, Stefan. General report: protection and preservation of cultural heritage in the impact of uniform laws on the protection of cultural heritage and the preservation of cultural heritage in the $21 \mathrm{st}$ century. Leiden: Brill; Nijhoff, 2010. p. 52. 
perils posed to such heritage and solutions for preservation and protection. ${ }^{38}$

Compared to the former 1970 UNESCO Convention, the 1972 World Heritage Convention presents a more proactive and effective mechanism underpinned and promoted by the co-operation between States Parties and the advisory bodies. Specifically, States Parties are more engaged in and take the initiative in forming inventories of heritage properties referred to as "tentative lists" by following the criteria provided by the World Heritage Committee in the WHC Operational Guidelines. States Parties then nominate heritage objects to be considered for inclusion in the World Heritage List. Depending on the type of a property, whether cultural or natural, a corresponding specialised advisory of the World Heritage Committee shall evaluate and determine which property shall be included in the World Heritage List. ${ }^{39}$

By participating in the 1972 World Heritage Convention, States Parties compromise on their sovereignties to allow the World Heritage Committee to make decisions aimed at heritage protection. Specifically, based on the criteria and guidance given under the Convention and the WHC Operational Guidelines, ${ }^{40}$ the World Heritage Committee reserves the right to inscribe heritage objects in the List of World Heritage in Danger and also revise this List without obtaining the consent of States Parties of origin ${ }^{41} .^{42}$

In addition, in the same manner to the implementation of the 1970 UNESCO Convention, the World Heritage Committee additionally paved the way for the implementation of the 1972 World Heritage Convention by imposing mandatory and optional financial contributions on States Parties with the aim of financing

\footnotetext{
381972 World Heritage Convention art 11; KONO, Toshiyuki; WRBKA, Stefan. General report: protection and preservation of cultural heritage in the impact of uniform laws on the protection of cultural heritage and the preservation of cultural heritage in the $21 \mathrm{st}$ century. Leiden: Brill; Nijhoff, 2010. p. 53.

39 WHC Operational Guidelines chapters II.C and III; KONO, Toshiyuki; WRBKA, Stefan. General report: protection and preservation of cultural heritage in the impact of uniform laws on the protection of cultural heritage and the preservation of cultural heritage in the 21st century. Leiden: Brill; Nijhoff, 2010. p. 55.

401972 World Heritage Convention art 11(4); WHC Operational Guidelines chapter IV.B.

${ }^{41}$ WHC Operational Guidelines. para 183.

42 KONO, Toshiyuki; WRBKA, Stefan. General report: protection and preservation of cultural heritage in the impact of uniform laws on the protection of cultural heritage and the preservation of cultural heritage in the 21 st century. Leiden: Brill; Nijhoff, 2010. p. 58.
}

the Fund for the Protection of the World Cultural and Natural Heritage (the "World Heritage Fund"). ${ }^{43}$

\subsection{Convention for the Safeguarding of Intangible Cultural Heritage (2003) (“2003 ICH Convention")}

The 2003 ICH Convention is another key and popular convention on heritage protection with 179 States Parties ${ }^{44} .5$ The four main purposes prescribed in Article 1 of this Convention constituting the safeguarding system thereof, including (i) safeguarding intangible cultural heritage, (ii) ensuring respect for the intangible cultural heritage of the communities, groups and individuals concerned; (iv) raising awareness of the importance of intangible cultural heritage; and (v) providing international cooperation and assistance. ${ }^{46}$

In the text of the Convention, intangible cultural heritage is broadly defined as not only "referring to a great number of various forms and methods of cultural identity" but as "being linked to its origin, mostly local, but not bound to the territory of a single State Party as it assigns the respective object to communities, groups and, in some cases, individuals" and the inheritance of intangible cultural heritage through different generations. ${ }^{47}$ Unlike the 1972 World Heritage Convention "where the core value was the 'outstanding' quality of a certain manifestation of heritage", the 2003 ICH Convention underlines the value of "the representativeness of the manifestation of heritage and consequently its contribution to cultural diversity". ${ }^{48}$ The meaning of using the term "representative" is to "avoid a ranking system" and "show the richness of cultural diversity and the importance and significance of intangible cultural heritage for its bearers - the communities, groups or individuals". ${ }^{49}$

\footnotetext{
$43 \quad 1972$ World Heritage Convention art 15.

44 As of 23 July 2020.

45 UNESCO. The States Parties. The Convention for the Safeguarding the Intangible Cultural Heritage. 2003. Available at: https://ich.unesco. org/en/states-parties-00024.

462003 ICH Convention art 1; LIXINSKI, Lucas. Intangible cultural beritage in international law. Oxford University Press, 2013. p. 40.

472003 ICH Convention art 2(1); KONO, Toshiyuki; WRBKA, Stefan. General report: protection and preservation of cultural heritage in the impact of uniform laws on the protection of cultural heritage and the preservation of cultural heritage in the 21 st century. Leiden: Brill; Nijhoff, 2010. p. 89.

48 LIXINSKI, Lucas. Intangible cultural heritage in international law. Oxford University Press, 2013. p. 36.

49 KONO, Toshiyuki; WRBKA, Stefan. General report: protection and preservation of cultural heritage in the impact of uniform laws
} 
Another significant feature of the 2003 ICH Convention is the interconnection between intangible cultural heritage and international human rights standards by referring to international human rights treaties in the Preamble and the definition of intangible cultural heritage. At this juncture, Lucas Lixinski pointed to rituals and social practices as the main elements linking intangible cultural heritage and human rights standards. ${ }^{50}$

Constructed in line with the 1972 World Heritage Convention, the 2003 ICH Convention follows the same model and considers States Parties main addressees. States Parties have the obligation of safeguarding intangible cultural heritage in their territories but "not limited to safeguarding measures related to heritage inscribed on the Representative List of Intangible Cultural Heritage of Humanity". ${ }^{51}$ Like the former conventions, the 2003 ICH Convention also sets up the Fund for the Safeguarding of the Intangible Cultural Heritage contributed by compulsory or voluntary payments by States Parties to ensure the implementation of the Convention. $^{52}$

In addition, the $2003 \mathrm{ICH}$ Convention shows the difference from the former 1972 World Heritage Convention where establishing the General Assembly of States as "the sovereign body of the convention" 53 and the Intergovernmental Committee for the Safeguarding of the Intangible Cultural Heritage ${ }^{54}$ focusing on promoting and assisting in the implementation of the Convention, and more importantly, having competencies to inscribe heritage objects in the two lists including the Representative List of the Intangible Cultural Heritage of Humanity and the List of Intangible Cultural Heritage in Need of Urgent Safeguarding. ${ }^{55}$

Under the 2003 ICH Convention, the participation

on the protection of cultural heritage and the preservation of cultural heritage in the 21st century. Leiden: Brill; Nijhoff, 2010. p. 94.

50 LIXINSKI, Lucas. Intangible cultural heritage in international law. Oxford University Press, 2013. p. 36.

512003 ICH Convention arts 11 and 12; KONO, Toshiyuki; WRBKA, Stefan. General report: protection and preservation of cultural heritage in the impact of uniform laws on the protection of cultural heritage and the preservation of cultural heritage in the 21 st century. Leiden: Brill; Nijhoff, 2010. p. 91-92.

522003 ICH Convention art 25(3).

532003 ICH Convention art 4(1).

542003 ICH Convention art 5(1).

55 KONO, Toshiyuki; WRBKA, Stefan. General report: protection and preservation of cultural heritage in the impact of uniform laws on the protection of cultural heritage and the preservation of cultural heritage in the 21st century. Leiden: Brill; Nijhoff, 2010. p. 93. of "communities, groups, and relevant non-governmental organisations" in assisting States Parties in formulating the inventories and implementing measures to safeguard intangible cultural heritage is recognised and more proactive. ${ }^{56}$ In this regard, Lucas Lixinski opined that "the Convention sees communities as not only the bearers of intangible cultural heritage entitled to assistance, but also the primary responsible parties for the safeguarding of intangible heritage". ${ }^{57}$

\subsection{Convention on the Protection and Promotion of the Diversity of Cultural Expression (2005) ("2005 UNESCO Convention")}

This Convention introduces a dissimilar approach compared to the former conventions. Whereas the former conventions concentrate on protecting or safeguarding heritage in various forms, the 2005 UNESCO Convention is a widely-acknowledged international treaty that "recognises the pursuit of the diversity of cultural expressions as a legitimate goal of governmental policy", 58 in particular, to "ensure artists, cultural professionals, practitioners and citizens worldwide can create, produce, disseminate and enjoy a broad range of cultural goods, services and activities, including their own". ${ }^{59}$ Along with respecting State sovereignty, the Convention lays down rights and obligations for States Parties to observe ${ }^{60} .{ }^{61}$ The UNESCO evaluated that the advent of the 2005 UNESCO Convention is "essen-

562003 ICH Convention arts 11 and 15; KONO, Toshiyuki; WRBKA, Stefan. General report: protection and preservation of cultural heritage in the impact of uniform laws on the protection of cultural heritage and the preservation of cultural heritage in the 21 st century. Leiden: Brill; Nijhoff, 2010. p. 91-92.

57 LIXINSKI, Lucas. Intangible cultural heritage in international law. Oxford University Press, 2013. p. 37-38.

58 GRABER, Christoph Beat. The New UNESCO Convention on Cultural Diversity: a counterbalance to the WTO?. Journal of International Economic Law, v. 9, n. 3, p. 553-574. p. 559.

59 UNESCO. What is the Convention. The Convention on the Protection and Promotion of the Diversity of Cultural Expressions. Available at: http://www.unesco.org/new/en/culture/themes/ cultural-diversity/cultural-expressions/the-convention/whatis-the-convention/\#: :text $=$ The $\% 20$ Convention $\% 20$ on $\% 20$ the $\% 20$ Protection, cultural $\% 20$ goods $\% 2 \mathrm{C} \% 20$ services $\% 20$ and $\% 20$ activities\%2C. Access on: 22 Sep. 2020.

60 2005 UNESCO Convention chapter IV.

${ }^{61}$ KONO, Toshiyuki; WRBKA, Stefan. General report: protection and preservation of cultural heritage in the impact of uniform laws on the protection of cultural heritage and the preservation of cultural heritage in the 21 st century. Leiden: Brill; Nijhoff, 2010. p. 104 106. 
tial for inclusive economic growth, reducing inequalities and achieving the goals set out in the 2030 Sustainable Development Agenda" and "at the heart of the creative economy". ${ }^{2}$

Following the same model to the first-mentioned conventions, the implementation process of the 2005 UNESCO was structured with the foundations of the Intergovernmental Committee for the Protection and Promotion of the Diversity of Cultural Expressions and the International Fund for Cultural Diversity to encourage and promote States Parties to protect and promote the cultural pluralism and diversity within their territories. ${ }^{63}$ Nevertheless, contributions to the fund under the regime of the 2005 UNESCO Convention are voluntary. No obligatory contributions by States Parties are required. ${ }^{64}$

\section{Overview of the Cultural Heritage Conventions under the Auspices of UNESCO}

In general, the UNESCO Conventions on heritage protection have the same modality and are "designed as self-contained regimes". ${ }^{65}$ Nevertheless, heritage international law is flawed considering its formulation. Lucas Lixinski held the opinion that the law on heritage is decided by a group of experts rather than the cultural owners. ${ }^{66}$

In light of the sovereignty of States, under all the conventions in the UNESCO system, States Parties are the primary addressees obliged to protect heritage in their territories. To support and promote States' adoption of heritage protective measures, the conventions additionally involve other non-State actors such as communities and non-governmental organisations. However, the degree of community involvement is inconsistent amongst the conventions.

${ }^{62}$ UNESCO. The Convention on the Protection and Promotion of the Diversity of Cultural Expression. Available at: https://en.unesco.org/ creativity/convention.

632005 UNESCO Convention arts 18(1) and 23(6)a.

642005 UNESCO Convention art 18(3).

65 FORREST, Craig. International law and the protection of cultural heritage. Routledge, 2010. p. 390.

${ }^{66}$ LIXINSKI, Lucas. International cultural heritage regimes, international law, and the politics of expertise. International Journal of Cultural Property, v. 20, p. 407-409, 2013. p. 414.
As State sovereignty lies at the heart of the UNESCO conventions, this accordingly makes the conventions heavily censured and constitutes a weakness in their application. From Lucas Lixinski's perspective, the "strongly sovereignty-based approach" facilitates the ratification of international legal instruments, but conversely, this approach can undermine the implementation of the instruments. Lucas Lixinski also pointed out that States Parties still have the overriding power to determine which heritage is to be protected or safeguarded. He went beyond descriptive analysis and referred to the application of the 2003 ICH Convention and the Tibetan Opera case, in particular. The Tibetan Opera case showed the successful inscription of Tibetan Opera in the Representative List of Intangible Heritage which can be considered "a laudable outreach initiative aimed at including Tibetan culture as part of the national Chinese culture, ultimately giving it a legitimacy that is denied in domestic political fora". Nevertheless, this case also received criticism that

by inscribing Tibetan cultural manifestations in this
list (and consequently in the national inventory),
the Chinese government actually asserts control
over the cultural manifestation, and the culture as a
whole, subordinating its political caveats to tourism
promotion and other economic interests, as well
as to a larger national Chinese identity, ultimately
diminishing the political strength of the Tibetan
culture and all political claims of Tibetans. ${ }^{67}$

In other words, the strongly sovereignty-based approach may pave the way for improper practice by States Parties in that they may take advantage of the regulations to justify and achieve their benefits rather than protect heritage.

As analysed above, even though the UNESCO conventions attempt to engage the participation of communities, communities can only take part at the national level and "seem not to have a space at the international level". ${ }^{68}$ The inscription of heritage considerably depends on the consultancy of experts. For instance, the preamble of the 1972 World Heritage Convention underlines the utilisation of experts to formulate a protective system for cultural and natural heritage that

\footnotetext{
67 LIXINSKI, Lucas. Intangible cultural heritage in international law. Oxford University Press, 2013. p. 52-53.

68 LIXINSKI, Lucas. Intangible cultural heritage in international law. Oxford University Press, 2013. p. 53; LIXINSKI, Lucas. International cultural heritage regimes, international law, and the politics of expertise. International Journal of Cultural Property, v. 20, p. 407-409, 2013. p. 416.
} 
is "organised on a permanent basis and in accordance with modern scientific methods". ${ }^{69}$ In addition, the members of the World Heritage Committee are "representatives of States Parties assisted by non-governmental organisations composed of experts in cultural heritage issues".$^{70}$ Furthermore, although the $2003 \mathrm{ICH}$ Convention acknowledges the community involvement in its text illustrates a considerable shift, the empowerment of communities and other stakeholders is still limited. $^{71}$

\section{Heritage Protection in Vietnamese Legislation}

\subsection{Strenuous efforts in formulating regulations on heritage protection before becoming a member to UNESCO's heritage conventions}

Vietnam has the richness and diversity of cultural heritage owing to more than a thousand years of history and ethnic diversity. Up to now, Vietnam has had 21 heritage properties endorsed by UNESCO in the World Heritage List ${ }^{72}$ and the Lists of Intangible Cultural Heritage, ${ }^{73} 105$ special natural heritage pro-

69 LIXINSKI, Lucas. International cultural heritage regimes, international law, and the politics of expertise. International Journal of Cultural Property, v. 20, p. 407-409, 2013. p. 414.

701972 World Heritage Convention art 8.3; LIXINSKI, Lucas. International cultural heritage regimes, international law, and the politics of expertise. International Journal of Cultural Property, v. 20, p. 407-409, 2013. p. 414.

712003 ICH Convention art 15; LIXINSKI, Lucas. International cultural heritage regimes, international law, and the politics of expertise. International Journal of Cultural Property, v. 20, p. 407-409, 2013. p. 416; LIXINSKI, Lucas. Intangible cultural heritage in international law. Oxford University Press, 2013. p. 55.

72 UNESCO. Vietnam: Properties inscribed on the World Heritage List. Available at: https://whc.unesco.org/en/statesparties/vn. Under the Word Heritage List, Vietnam 's world heritage properties include five cultural heritage properties which are Complex of Hue Monuments (1993), Hoi An Ancient Town (1999), My Son Sanctuary (1999), Central Sector of the Imperial Citadel of Thang Long - Hanoi (2010), and Citadel of the Ho Dynasty (2011); two natural heritage properties which are Ha Long Bay $(1994,2000)$ and Phong Nha - Ke Bang National Park (2003, 2015); and one mixed heritage property as Trang An Landscape Complex (2014).

73 UNESCO. Vietnam: Elements on the Lists of Intangible Cultural Heritage. Available at: https://ich.unesco.org/en/state/vietnam-VN?info=elements-on-the-lists. Under the Lists of Intangible Cultural Heritage, Vietnam's intangible cultural heritage properties are comprised of Space of gong cultural (2008), Nha Nhac, Viet- perties, 3,494 natural heritage properties, nearly 10,000 city/province-level ranking heritage properties, 301 intangible cultural heritage elements inscribed in the $\mathrm{Na}$ tional Intangible Heritage List, 164 objects and object groups recognised as national treasures. The museum system has been expanded with a total number of 167 museums (including 125 public museums and 42 private museums). ${ }^{74}$ These are extremely rich and unique resources for localities across the country to exploit and develop tourism, contributing to poverty reduction, and promoting and improving people's livelihoods.

The Report on the work of culture, sports and tourism in 2017 of the Ministry of Culture, Sports and Tourism additionally affirmed that Vietnamese cultural heritage is the crystallization of the traditions, wisdom, and sentiment of preceding generations. Despite experiencing numerous historical events such as wars, causing significant damage and destruction, in addition to severe natural disasters, Vietnamese heritage properties remain rich and diverse. They have significantly influenced the formation of Vietnamese human personality traits in the past, present and future, and are important elements that directly contribute to the protection of the national identity, defence, and the country's development. ${ }^{75}$

During the period the State experienced the war, President Ho Chi Minh established the Vietnam Oriental Institute aimed to preserve all "antiques" within the territory of Vietnam through the issuance of the Act No. 65 dated 23 November 1945. The term "antiques" is construed to have the same meaning as "cultural he-

namese court music (2008); Quan Họ Bắc Ninh folk songs (2009), Ca trù singing (2009); Gióng festival of Phù Đổng and Sóc temples (2010); Worship of Hùng kings in Phú Thọ (2012); Art of Đờn ca tài tử music and song in southern Vietnam (2013); Vi and Giặm folk songs of Nghệ Tĩnh (2014); Tugging rituals and games (2015); Practices related to the Viet beliefs in the Mother Goddesses of Three Realms (2016); The art of Bài Chòi in Central Vietnam (2017), Xoan singing of Phú Thọ province, Vietnam (2017); Practices of Then by Tày, Nùng and Thái ethnic groups in Vietnam (2019).

${ }^{74}$ COMMUNIST PARTY OF VIETNAM. Bảo vệ và phát huy giá trị di săn văn hóa Việt nam vì sự phát triên bền vũng. [Protection and promotion of the values of Vietnamese cultural heritage for the aim of sustainable development]. Available at: http://dangcongsan.vn/ tu-tuong-van-hoa/bao-ve-va-phat-huy-gia-tri-di-san-van-hoa-vietnam-vi-su-phat-trien-ben-vung-491901.html.

75 COMMUNIST PARTY OF VIETNAM. Bảo vệ và phát huy giá trị di săn văn hóa Việt nam vì sụ phát triên bền vũng. [Protection and promotion of the values of Vietnamese cultural heritage for the aim of sustainable development]. Available at: http://dangcongsan.vn/ tu-tuong-van-hoa/bao-ve-va-phat-huy-gia-tri-di-san-van-hoa-vietnam-vi-su-phat-trien-ben-vung-491901.html. 
ritage". This Act set forth a prohibition on 'destroying temples, communal houses or other worship venues, palaces and tombs, stelae, objects, conferment, documents and texts, and books which bear religious characteristics or not, which are historically valuable but have not yet been safeguarded. ${ }^{76}$ Under this Act, despite suffering from financial difficulties during the war period and at the beginning of the declaration of independence, the Government allocated financial support to ensure the functionality of the Vietnam Oriental Institute in safeguarding Vietnamese heritage. This Act demonstrated the Government's initial effort and laid the groundwork for subsequent laws and policies in safeguarding heritage. In light of this Act, on the date of 24 February 2005, the Prime Minister of Vietnam adopted the Decision No. 36/QD-T'Tg to set forth the date of $23^{\text {rd }}$ November every year as the Vietnam Cultural Heritage Day to promote national traditions, raise public awareness of safeguarding cultural heritage properties and encourage communities' proactive involvement in cultural heritage protection. ${ }^{77}$

Vietnamese heritage objects were devastated in the aftermath of the wars which lasted for decades. Recognising the importance of cultural heritage to the recovery and development of the country's economy and society after the wars, the Government of Vietnam ratified all the core UNESCO conventions to better safeguard the country's heritage with the additional support from the international community. The 1972 World Heritage Convention was the first central UNESCO convention that Vietnam ratified. ${ }^{78}$ In the following years, the Government proceeded with the ratification of the other conventions. Specifically, Vietnam officially became a member of both the 1970 UNESCO Convention and the 2003 ICH Convention on the same date of 20 September $2005^{79}$, and the latter - the 2005 UNESCO

\footnotetext{
76 TU, Thi Loan. Cultural heritage in Vietnam with the requirements of sustainable development. International Relations and Diplomacy, v. 7, n. 4, p. 172-187. p. 173.

PHÁT huy giá trị di sản văn hóa, tạo cơ hội phát triển du lịch Promotion of cultural heritage values and creation of opportunities for tourism development]. Available at: http://tuyengiao.vn/ van-hoa-xa-hoi/van-hoa/phat-huy-gia-tri-di-san-van-hoa-tao-cohoi-phat-trien-du-lich-125393.

78 UNESCO. States Parties. Ratification Status of Vietnam. The Convention Concerning the Protection of the World Cultural and Natural Heritage. 1972. Vietnam ratified the 1972 World Heritage Convention on 19 October 1987. Available at: https://whc.unesco.org/en/ statesparties/.

79 UNESCO. States Parties. Ratification Status of Vietnam. The Convention on the Protection and Promotion of the Convention on the Means
}

Convention on 07 August 2007..$^{80}$

\subsection{The implementation of commitments arising from UNESCO's heritage conventions in the Vietnamese legal system}

Article 26 of the 1969 Vienna Convention on the Law of Treaties provides that "Every treaty in force is binding upon the parties to it and must be performed by them in good faith" ${ }^{81}$ This means that once signing and ratifying international treaties, a State is obliged to conduct its commitments with good faith and honesty and should not refer to its internal law to make excuses for its failure to conduct its obligations. ${ }^{82}$ Thus, comprehensive compliance in good faith with international treaties is a compulsory responsibility of State members, "unless a different intention appears from the treaty or is otherwise established, a treaty is binding upon each party in respect of its entire territory". 83

Based on that spirit of the 1969 Vienna Convention on the Law of Treaties, Article 6.2 of the 2016 Law on Treaties of Vietnam states that "Based on the requirements, content and nature of a treaty, the National Assembly, the President or the Government shall decide on the consent to be bound by the treaty and the application of the whole or part of the treaty to agencies, organizations and individuals if the provisions of the treaty are clear and detailed enough for implementation; or decide or propose the amendment and supplementation, annulment or promulgation of legal documents for the implementation of the treaty". According to this, Vietnam adopts a hybrid approach by recognising two ways of implementing international treaties to which the State is a member within its terri-

of Probibiting and Preventing the Illicit Import, Export and Transfer of Ownership of Cultural Property. 1970. Available at: https://pax.unesco.org/ la $/$ convention. asp?order $=$ alpha\&language $=\mathrm{E} \& \mathrm{KO}=13039$; $\quad \mathrm{UN}-$ ESCO. States Parties. Ratification Status of Vietnam. The Convention for the Safeguarding of the Intangible Cultural Heritage. 2003. Available at: https://pax.unesco.org/la/convention.asp? $\mathrm{KO}=17116 \&$ language $=$ E\&order=alpha.

80 UNESCO. States Parties. Ratification Status of Vietnam. The Convention on the Protection and Promotion of the Diversity of Cultural Expressions. 2005. Available at: https://pax.unesco.org/la/convention. asp $\mathrm{KO}=31038 \&$ language $=\mathrm{E} \&$ order $=$ alpha.

81 UNITED NATIONS. Vienna Convention on the Law of Treaties. Vienna, 23 May 1969. Treaty series, v. 1155, p. 331. Available at: https:// treaties.un.org $/$ Pages $/$ ViewDetailsIII.aspx?src=TREATY\&mtdsg_ no $=$ XXIII-1\&chapter $=23 \&$ Temp $=$ mtds $g 3$ \&clang $=\_e n$.

82 Vienna Convention on the Law of Treaties art 27.

83 Vienna Convention on the Law of Treaties art 29. 
tory which have direct application and are incorporated into national law. Nevertheless, in practice, almost all international treaties to which Vietnam is a member (including UNESCO's treaties) apply within the State by being incorporated into the national law, indicated by issuance of new laws or revision of existing laws. This additionally clarifies that organisations and individuals cannot refer to international law as a source of law before Vietnamese judicial authorities. In other words, unless incorporated into national law, Vietnamese courts have no jurisdiction to apply or construct international treaties. Nevertheless, once being incorporated into and becoming an integral part of national law, international treaties are turned into important legal bases for the executive and judicial activities of the State.

With the understanding that heritage protection is not a free-standing issue and pursuit of sustainable development goals, the Vietnamese Government has adopted a holistic approach by establishing and developing issuing a set of different laws and legal guiding documents to ensure the attainment of heritage safeguarding. This effort of the Vietnamese Government was recorded in the Final Periodic Report - First Cycle (2003)..$^{84}$

As a member of UNESCO Conventions, in 1994, the Government of Vietnam launched the National Programme for Safeguarding the National Cultural Heritage outlining general principles and policies for heritage preservation and protection. ${ }^{85}$ Thereafter, the Vietnamese Government introduced the Law on Cultural Heritage on $29^{\text {th }}$ June 2001 with the latest amendment on $18^{\text {th }}$ June 2009 , which lies at the heart of heritage protection legislation. In the preamble, the Vietnamese Government showed its strong respect for cultural heritage by stating that "Vietnamese cultural heritage is a valuable asset of the multi-ethnic Vietnamese community, a part of cultural heritage of humanity and plays a significant role in the national development and preservation of our people". The preamble of the 2001 Law

84 UNESCO. World Heritage Committee. Final periodic report: state of the world heritage in Asia and the Pacific. 2003 synthesis periodic report for the Asia-Pacific region. WHC-03/27.COM/6A. Paris, 16 June 2003. Available at: https://whc.unesco.org/archive/2003/ whc03-27com-06ae.pdf.

85 UNESCO. World Heritage Committee. Final periodic report: state of the world heritage in Asia and the Pacific. 2003 synthesis periodic report for the Asia-Pacific region. WHC-03/27.COM/6A. Paris, 16 June 2003. Available at: https://whc.unesco.org/archive/2003/ whc03-27com-06ae.pdf. on Cultural Heritage further affirms and highlights the application of this instrument with the primary aims of "safeguarding and promotion of cultural heritage values to contribute to the construction and development of Vietnam's progressive and unique culture and the treasured cultural heritage of the world" ${ }^{86}$ Heritage protection regulations are also found in numerous other legal documents such as the 2014 Law on Construction $^{87}$, the 2014 Law on Environmental Protection ${ }^{88}$, the 2017 Law on Forestry. ${ }^{89}$

In light of the 2013 Constitution of Vietnam ${ }^{90}$, the Vietnamese Government "emphasises the essential value of culture for the nation's citizens" and therefore recognise the role of communities as cultural owners in safeguarding heritage. However, apart from prescribing general rights and obligations of individuals and organisations to protect heritage objects, regulations on community participation in "discussions and decision-making processes related to either the tangible or intangible heritage they own or preserve" are absent under the 2001 Law on Cultural Heritage. ${ }^{91}$

Under the legal documents guiding the 2001 Law on Cultural Heritage, particularly Decree No. 70/2012/ ND-CP dated 18 September 2013, as later replaced by Decree No. 166/2018/ND-CP dated 25 December 2018 on the competence, sequence, procedures for the establishment and approval of master plans and projects on maintenance, repair and restoration of historical-cultural relics and scenic places, "relevant individuals and organisations" are entitled to provide opinions in the formulation of master plans and maintenance, repair and restoration of historical-cultural relics and scenic places. Nevertheless, the legal documents fail to identify "relevant individuals and organisations", which

86 VIETNAM. Law No. 28/2001/QH10 dated 23 July 2013. Cultural Heritage of the Socialist Republic of Vietnam. Available at: https://sherloc.unodc.org/res/cld/document/vnm/law-on-cultural-heritage_html/vn_law_cltal_heritage_engtof.pdf.

87 VIETNAM. Law No. 50/2014/QH13 dated 18 June 2014. Construction of the Socialist Republic of Vietnam.

88 VIETNAM. Law No. 55/2014/QH13 dated 23 June 2014. Environmental Protection of the Socialist Republic of Vietnam.

89 VIETNAM. Law No. 16/2017/QH14 dated 15 November 2017. Forestry of the Socialist Republic of Vietnam.

90 VIETNAM. [Constitution (2013)]. Constitution of the Socialist Republic of Vietnam.

91 NGUYEN, Linh Giang. World heritage and human rights policy in Vietnam: a legal review. In: LARSEN, Peter Biller. World heritage and buman rights: lessons from the Asia. Routledge, 2018. p. 277. 
consequently engenders difficulties in practice. ${ }^{92}$

Besides, William Logan opined that compared to UNESCO conventions, the 2001 Law on Cultural Heritage is more stringent "in insisting on the removal of residents from inscribed properties, even when they may have lived there for generations and have no major negative impact on the Outstanding Universal Value of the properties". ${ }^{93}$ Further, Nguyen Linh Giang held the opinion that the 2001 Law on Cultural Heritage and other legal guiding documents focus on "ensuring the national strategy and objectives of socio-economic development; national defence and security development planning" without considering "the rights of people living in heritage sites or to the stability and development of people's living standards within the heritage planning process". ${ }^{94}$ This author also referred to the case of Hoi An Ancient Town recognised as a Cultural World Heritage site by UNESCO in 1999 as a typical example for difficulties in practice caused to people living in the heritage site from the implementation of the regulations on heritage protection. In particular, according to the applicable regulations, in case of renovation, repair or restoration, house owners or management organs in Hoi An Ancient Town are required to send proposal documents on the same to several authorities including the Department of Culture, Sport and Tourism, the Ministry of Culture, Sport and Tourism and the Ministry of Construction, which is stricter than normal construction cases and not practical for people living in the heritage site..$^{95}$

Along with the introduction and revision of the 2001 Law on Cultural Heritage, it was recorded that the Vietnamese Government established "an innovative 'National Heritage Council' directly under the Prime Minister" $" 96$ to be mainly responsible for heritage pro-

\footnotetext{
92 NGUYEN, Linh Giang. World heritage and human rights policy in Vietnam: a legal review. In: LARSEN, Peter Biller. World heritage and human rights: lessons from the Asia. Routledge, 2018. p. 278.

93 LOGAN, William Logan. Collective cultural rights in Asia: recognition and enforcement. In: JAKUBOWSKI, Andrzej. Cultural rights as collective rights: an international law perspective. Leiden: Brill; Nijhoff, 2016. p. 194.

94 NGUYEN, Linh Giang. World heritage and human rights policy in Vietnam: a legal review. In: LARSEN, Peter Biller. World heritage and human rights: lessons from the Asia. Routledge, 2018. p. 285-286. 95 NGUYEN, Linh Giang. World heritage and human rights policy in Vietnam: a legal review. In: LARSEN, Peter Biller. World heritage and human rights: lessons from the Asia. Routledge, 2018. p. 279-280. 96 UNESCO. World Heritage Committee. Final periodic report: state of the world heritage in Asia and the Pacific. 2003 synthesis periodic
}

tection. The Government additionally set out the Cultural Heritage Day as one of the numerous activities to promote heritage protection and raise the awareness of citizens about the values of cultural heritage. ${ }^{97}$ For educational and awareness-building purposes, Vietnamese governmental agencies launched and conducted numerous programmes and projects such as World Heritage property voluntary programme in Ha Long Bay in the 2008-2009 period within the scope of the World Heritage in Young Hands, and "Child-friendly school" programme in the 2010-2011 period "which contributed to raise awareness of students in safeguarding cultural and natural properties". ${ }^{98}$ The Government's effort in arranging managements in heritage protection with the direct participation of local governmental agencies and communities was recorded in the Final Report Second Cycle (2013). Particularly, the management board of Phong Nha Ke Bang National Park cooperated with the local government authorities in performing safeguarding measures between 2003 and 2010, and also formulating and issuing various legal documents for the management of the heritage property, "which led to the improved management and protection of ecological environment and socio-economic activities in the property". ${ }^{99}$

In addition, the Government issued Decree No. 109/2017/ND-CP dated $21^{\text {st }}$ September 2017 regulating the protection and management of world natural and cultural heritage, which is a meaningful legal instrument in heritage safeguarding to both national and international communities. Specifically, for the purpose of recognising outstanding contributions of artists in the transmission, safeguarding and promotion of cultural heritage values, the Government issued Decree No. 62/2014/ ND-CP dated $25^{\text {th }}$ June 2014 on awarding titles "People's Artist" and "Meritorious Artiste" in the field of intan-

report for the Asia-Pacific region. WHC-03/27.COM/6A. Paris, 16 June 2003. Available at: https://whc.unesco.org/archive/2003/ whc03-27com-06ae.pdf.

${ }^{97}$ UNESCO. World Heritage Committee. Final report on the results of the second cycle of the Period Reporting exercise for Asia and the Pacific. WHC-12/36.COM/10A. Paris, 01 June 2012. Available at: https:// whc.unesco.org/archive/2012/whc12-36com-10A-en.pdf.

98 UNESCO. World Heritage Committee. Final report on the results of the second cycle of the Period Reporting exercise for Asia and the Pacific. WHC-12/36.COM/10A. Paris, 01 June 2012. Available at: https:// whc.unesco.org/archive/2012/whc12-36com-10A-en.pdf.

99 UNESCO. World Heritage Committee. Final report on the results of the second cycle of the Period Reporting exercise for Asia and the Pacific. WHC-12/36.COM/10A. Paris, 01 June 2012. Available at: https:// whc.unesco.org/archive/2012/whc12-36com-10A-en.pdf. 
gible cultural heritage. For artists honoured as people's artists and meritorious artistes with low incomes and in difficult circumstances, the Government, throughout the adoption of Decree No. 109/2015/ND-CP dated $28^{\text {th }}$ October 2015, has approved the provision of financial support to such artistes including monthly allowances for living expenses, health insurance, and funeral costs with three levels of financial supporting amounts of VND 1 million, VND 850,000, and VND 700,000 per person per month, respectively. This legal document is considered a humane instrument and a "bright spot" showing the Government's attention and support to people who have dedicated themselves to the transmission of Vietnamese traditional cultural values even though Vietnam is still a developing country and in the difficult context of recovering in the aftermath of the wars.

The Government additionally laid forth regulations on sanctioning violations against cultural heritage. Depending on the violation severity levels, violators may be subject to administrative sanctions according to the 2012 Law on Handling of Administrative Violations, Decree No. 158/2013/ND-CP regulating the sanctioning of administrative violations in the field of culture and the 2001 Cultural Heritage Law (amended in 2009), or may face criminal liabilities under the 2017 Criminal Code 2015 (amended in 2017), for example, Article 345 regulating violations of regulations on the protection and use of historical-cultural relics and famous landscapes that lead to serious consequences, or Article 178 dealing with the crime of destroying relics and antiques.

Whereby:

Those who violate the regulations on the protection and use of historical-cultural relics, famous places or landscapes, causing damage to historical-cultural relics, landscapes or landscapes with the value from VND 100,000,000 to under VND 500,000,000; destroying or altering the original elements that constitute historical-cultural relics, provinciallevel landscapes, or have been administratively sanctioned for this act or have been convicted of this crime, or with a criminal conviction but still in violation, they shall be subject to a warning, a fine of between VND 10,000,000 and 100,000,000, a fine of up to 03 years of non-custodial reform or a prison term of between 06 months and 03 years.

Committing the crime in the case of damaging historical-cultural relics, landscapes or landscapes valued at VND 500,000,000 or more or destroying or changing the original elements constituting historical relics - culture and scenic spots at the national level or at a special national level shall be sentenced to between 3 and 7 years' imprisonment.
Up to now, Vietnam has built up a relatively complete legal system for the protection of cultural heritage and created a basic legal framework to recognize the rights and obligations of the State and other subjects in protecting and promoting the values of cultural heritage. These documents are consistent with international treaties to which Vietnam has acceded. However, the issue of the preservation and promotion of cultural heritage values in Vietnam today is still encountering difficulties which require resolutions. The rights and benefits of people and communities living in heritage sites or owning heritage objects should be taken into account and strengthened to trigger and encourage their proactive engagement in and contribution to the heritage safeguarding. The relationship between cultural identity preservation and international integration and economic development has always been an internal concern of all countries, including Vietnam. Hence, in the next section of the article, we will focus on clarifying the real problems or challenges facing Vietnam in the process of preserving its diverse cultural heritages.

\section{Challenges in the Preservation and Safeguarding of Cultural Heritage in Vietnam}

As mentioned above, cultural heritage properties are the most vivid evidence reflecting the spirits and spiritual values of the people of Vietnam and the existence of cultural heritage is considerably meaningful to the national history, culture and economy. Although Vietnam is a land of cultural diversity with thousands of tangible and intangible heritage properties, Vietnam has been facing challenges and difficulties in the preservation and promotion of the value of the heritage properties.

The first challenge which is seen as crucial is the public's awareness of the values conveyed by heritage. To date, this awareness is neither profound nor comprehensive, and the observance of regulations on respect and protection of heritage is still relatively poor. The preservation and promotion of cultural heritage conservation are the responsibilities of not only the State but also communities - actual cultural creators and owners. As cultural heritage, historical and cultural relics are not regenerable or replaceable. In principle, 
it is prohibited to devastate or adversely affect cultural heritage properties' values, authenticity, original constituting factors, and integrity. However, in recent times, heritage devastation cases have still occurred. In specific, Son Tra peninsula, which is considered a "green lung" of Da Nang city, was intruded by a series of illegal construction works. Another violating case was detected in Trang An Landscape Complex in Ninh Binh Province where a giant construction work for tourism was unlawfully executed at the heart of the landscape site project. Illicit construction of a statue at Sam Mountain was also discovered. ${ }^{100}$ In light of the present situation, Vietnam needs to intensify monitoring activities, strengthen the protection and safety of cultural heritage properties, particularly those which have been inscribed by UNESCO. Effective measures to be taken include education and dissemination of knowledge to improve public awareness of the importance of heritage elements and communities' responsibilities in safeguarding heritage.

The second challenge is the impact of globalization on the preservation of national cultural heritages. The process of innovation and globalization is having an increasing impact on cultural heritages, with cultural heritages facing fierce challenges in light of industrialization, modernization, urbanization and market economy mechanisms. Many fine customs and practices have been restored in several places, but in numerous places have gradually faded. The individual role in creation and development is highly appreciated, but also because of that, the community is declining. In addition, the trend of economic globalization and cultural internationalization, on the one hand, creates opportunities and conditions for the protection of traditional cultural values of each country, but the danger of destroying traditional cultural values and threatening the survival of cultural heritages also arises as a result. ${ }^{101}$

In reality, Vietnam has yet to strike the balance between heritage protection and economic development. Some famous heritage sites are overexploited for com-

\footnotetext{
100 XỬ lý hiệu quả hành vi vi phạm di sản quốc gia [Effective dealing with violations against national heritage properties]. Available at: https://nhandan.com.vn/di-san/xu-ly-hieu-qua-hanh-vi-xampham-di-san-quoc-gia-375905/.

101 VIETNAM. Ministry of Culture, Sports and Tourism. Bảo vệ $d i$ sản bằng súc mạnh và trách nhiệm cộng đồng. [Heritage protection with communities' strength and responsibility]. Available at: https:// bvhttdl.gov.vn/bao-ve-di-san-bang-suc-manh-va-trach-nhiemcong-dong-620018.htm.
}

mercial purposes, overloaded by tourists, or improperly restored and renovated, causing degradation and deterioration. Following a community-based approach, it is a truism that heritage preservation without generating benefits to communities will not be sustainable. However, overexploitation and over-tourism damage can ruin heritage properties, causing the permanent loss of heritage, cultural identity, community spirit and pride. Thereby, to develop sustainable tourism on the basis of utilising cultural heritage, it is required for the Vietnamese Government to adopt an appropriate sustainable development strategy. The tourism industry should develop new tourism products based on cultural heritage, associated with community culture and respecting cultural diversity, promoting the role of indigenous cultures, contributing to raising awareness, protecting interests and bringing into play the role of local communities in the development of cultural and heritage tourism.

Detecting and filling the gaps and shortcomings of the legal system related to the protection of cultural heritages is also an issue that Vietnam needs to focus on in the coming time. As noted in Section 4, the provisions of Vietnamese law relating to the conservation of cultural heritages are, in general, quite consistent with the spirit and content of the UNESCO Conventions. Achieving this outcome is not easy, especially for a developing country like Vietnam, where the economy and reduction of poverty remaining prominent issues. However, it is also necessary to objectively acknowledge that laws and guiding documents in this area contain gaps and lack effectiveness. As Prime Minister - Nguyen Xuan Phuc said, "While the law has been enacted it has not yet been strictly enforced... it remains unclear whether the responsibility in preserving, repairing and embellishing relics and heritages makes the heritage protections work well in many places, and heritages have been compromised ". ${ }^{102}$ Specifically:

First, regulations on rights and obligations of entities are not very clear or specific. The 2001 Law on Cultural Heritage only provides general provisions on the rights and obligations of organizations and individuals in the matter of preserving and protecting cultural heritage, especially in the protection of physical cultural

102 VIETNAM. Ministry of Culture, Sports and Tourism. Bảo vệ di sản bằng súc mạnh và trách nhiệm cộng đông. [Heritage protection with communities' strength and responsibility]. Available at: https:// bvhttdl.gov.vn/bao-ve-di-san-bang-suc-manh-va-trach-nhiemcong-dong-620018.htm. 
values. Meanwhile, the intangible cultural heritages are the basic values that create the essence and create the identity, the values of the traditional culture are rarely mentioned.

Second, the sanctions for handling administrative violations in the protection, preservation and promotion of traditional cultural values are not strict enough to punish and discourage violations; acts of distorting history, denying revolutionary achievements. The level of enforcement is not strict enough, just stopping at the level of administrative sanctions.

Third, the policy regime for officers participating in the collection of intangible cultural heritage has not been specified.

Fourth, financial mechanisms and policies for the conservation of new cultural heritage stop at general regulations or are not synchronous, complete, or comprehensive. They have only been recognized in a number of aspects such as expenses for artisans, excavation expenses, archaeology, and others.

Therefore, to enhance the role of law in preserving cultural heritages, the Government of Vietnam should step up the construction, systematization, and step by step improve the legal system; continue to issue and implement preferential policies for artisans, create conditions for artisans to practice and preserve their heritage, and encourage artisans to pass on their knowledge and skills to the next generation; and at the same time, strengthen the organization and implementation of the law and strictly and promptly handle violations of the law and the cultural values of the nation that are in need of conservation and development. In addition, it is necessary to improve and complement legal documents on financial mechanisms and policies in the field of cultural heritage protection and management on the basis of synthesis, research and proposal of financial support policies to investment in conservation of cultural heritage ${ }^{103}$, and focus on reforming the state management apparatus in terms of culture in all three aspects: institutions, apparatus and contingent of cadres and civil servants performing the function of cultural construc-

\footnotetext{
103 NGUYEN, Thanh Hien. Cơ chế, chính sách tài chính đối với công tác bảo tồn di sản văn hóa Việt Nam. [Mechanisms, financial policies for cultural heritage of Vietnam]. Tapp chí Täi chính [Journal of Finance], v. 2. Available at: https://tapchitaichinh.vn/co-chechinh-sach/co-che-chinh-sach-tai-chinh-doi-voi-cong-tac-bao-tondi-san-van-hoa-viet-nam-330691.html.
}

tion and development. ${ }^{104}$

Besides the aforementioned issues, the limited investment and financial sources available for heritage conservation poses another concern to the Government. Vietnam is a developing country with the current GDP per capita about USD (around 2,800 USD in 2019 ) is only $40 \%$ of the global average, $20 \%$ of the average of the Association of Southeast Asian Nations (ASEAN) and $5 \%$ the average of the high-income economies. ${ }^{105}$ As mentioned above, Vietnam has a diversity of cultural heritage properties located in numerous areas across the country. Some types of intangible heritage are on the verge of loss, particularly traditional arts. Numerous historical monuments and sites have sharply deteriorated and degraded, requiring considerable restoration. However, funding sources from the State budget only partially supports the protection of heritage against degradation or helps to prolong their lives. Some local communities living in poor areas are unable to donate sufficient money to large-scale restoration or renovation.

In addition, the implementation of support to artists in heritage preservation is slow and inefficient. Folk artists are those who hold the quintessential values of traditional culture and arts, traditional crafts and are honoured by UNESCO as living human treasures. As said above, the issuance of Decree No. 109/2015/ ND-CP by the Vietnamese Government illustrates the Government's significant support to artists having low incomes and in difficult circumstances. The honour of artists shows the respect of communities to those who have constantly devoted and dedicated their lives to the preservation and safeguarding of cultural heritage of the localities and the State. Nevertheless, it is only practically effective where honoured artists' livelihoods are maintained, paving the way for their contributions to the enrichment of traditional cultural values to communities and the transmission of their knowledge and skills to the younger generations. ${ }^{106}$ Nevertheless, in

104 HO, Thanh Hon. Vai trò của pháp luật trong giữ gìn, phát huy giá trị văn hóa truyền thống. [The role of laws in preserving and promoting traditional and cultural values]. Tạp chí Ngbiên cứu Lâp pháp [Journal of Legislative Studies], v. 7, n. 359. Available at: http:// lapphap.vn/Pages/tintuc/tinchitiet.aspx?tintucid $=207028$.

105 WORLD BANK GROUP. Vibrant Vietnam: forging the foundation of a high-income economy: main report. May 2020. Available at: https://documents.worldbank.org/curated/ en/745271590429811414/pdf/Main-Report.pdf.

106 NHAN DAN ONLINE NEWS. Shortcomings in supporting folk 
fact, very few artists, specifically those living in poor, remote, and mountainous areas can enjoy these supportive policies due to inefficient implementation and poor management. The majority of artists are still living in poverty without allowances or insurance. Furthermore, the Government has yet to develop a long-term development strategy to facilitate the preservation of traditional cultural values and beneficial working conditions for artists ${ }^{107}$. Thereby, in the future, the Government is in need of policies on maintaining artists' livelihoods and facilitating working conditions for artists to pave the way for their contributions through conveying their knowledge and skills to others.

Although a firm legal corridor on heritage protection has been created, there is a lack of conformity in the legal framework and policies in these regards. The Law on Cultural Heritage has not yet provided comprehensive solutions to regulate and assign specific responsibilities of State management authorities and monument owners, the involvement of communities and expertise entities and their interconnections with the State authorities in heritage protection, and the implementation processes of heritage protection. Moreover, it is necessary to promote integration and international exchange in heritage protection and management as cultural exchanges are inevitable as well as the Government adhering to commitments to UNESCO and the international community.

\section{Conclusion}

Preservation and promotion of the nation's cultural heritage property are the common responsibility of both the State and communities, particularly inscribed cultural heritage properties. All States are confronted with the issue of how to ensure socio-economic development and heritage safeguarding simultaneously. In recent years, the Government of Vietnam has made strenuous efforts to create an important legal corridor for the preservation of the country's cultural heritage. Nevertheless, due to limitations in resources and social awareness and weaknesses in the State management

artists. Available at: https://nhandan.com.vn/dong-chay/bat-captrong-dai-ngo-nghe-nhan-dan-gian-327225/.

107 NHAN DAN ONLINE NEWS. Shortcomings in supporting folk artists. Available at: https://nhandan.com.vn/dong-chay/bat-captrong-dai-ngo-nghe-nhan-dan-gian-327225/. operation, heritage protection remains a difficulty to the Government of Vietnam.

It is difficult to have cultural heritage objects inscribed; however, it is even more difficult to safeguard them and promote their values. Preserving heritage is akin to preserving the nation's soul, cultural roots, and traditions, which requires citizens, organisations and the State to take responsibility. In addition to the continuous implementation of domestic regulations on heritage protection, the Vietnamese Government is required to balance between economic development demands and heritage safeguarding and draw attention to the development of supportive policies for artists. Vietnam additionally needs to consider incorporating provisions contained in the international treaties on heritage protection to which Vietnam is a member. Concurrently, it is necessary to strengthen international cooperative activities to seek further assistance in heritage safeguarding and apply scientific and technological achievements to enhance heritage management and supervision in the future.

\section{References}

COMMUNIST PARTY OF VIETNAM. Bảo vệ và phát buy giá trị di săn văn hóa Việt nam vì sư phát triên bền vĩng. [Protection and promotion of the values of Vietnamese cultural heritage for the aim of sustainable development]. Available at: http://dangcongsan.vn/tutuong-van-hoa/bao-ve-va-phat-huy-gia-tri-di-san-vanhoa-viet-nam-vi-su-phat-trien-ben-vung-491901.html.

FORREST, Craig. International law and the protection of cultural heritage. Routledge, 2010.

HO, Thanh Hon. Vai trò của pháp luật trong giữ gìn, phát huy giá trị văn hóa truyên thống. [The role of laws in preserving and promoting traditional and cultural values]. Tạp chi Nghiên cứu Lạppháp Journal of Legislative Studies], v. 7, n. 359. Available at: http://lapphap.vn/ Pages $/$ tintuc/ tinchitiet.aspx?tintucid $=207028$.

HUMAN RIGHTS COUNCIL. Report of the Independent Expert in the Field of Cultural Rights, Farida Shaheed. No. A/HRC/17/38. 21st Mar. 2011. Available at: https:/ / undocs.org/pdf?symbol=en/A/HRC/17/38.

KONO, Toshiyuki; WRBKA, Stefan. General report: protection and preservation of cultural heritage in the 
impact of uniform laws on the protection of cultural heritage and the preservation of cultural heritage in the 21st century. Leiden: Brill; Nijhoff, 2010.

LIXINSKI, Lucas. Intangible cultural heritage in international law. Oxford University Press, 2013.

LIXINSKI, Lucas. International cultural heritage regimes, international law, and the politics of expertise. International Journal of Cultural Property, v. 20, p. 407-409, 2013.

LOGAN, William Logan. Collective cultural rights in Asia: recognition and enforcement. In:JAKUBOWSKI, Andrzej. Cultural rights as collective rights: an international law perspective. Leiden: Brill; Nijhoff, 2016.

NGUYEN, Linh Giang. World heritage and human rights policy in Vietnam: a legal review. In: LARSEN, Peter Biller. World heritage and human rights: lessons from the Asia. Routledge, 2018.

NGUYEN, Thanh Hien. Cơ chế, chính sách tài chính đối với công tác bảo tôn di sản văn hóa Việt Nam. [Mechanisms, financial policies for cultural heritage of Vietnam]. Tạp chi Tài chinh [Journal of Finance], v. 2. Available at: https://tapchitaichinh.vn/co-che-chinh-sach/ co-che-chinh-sach-tai-chinh-doi-voi-cong-tac-bao-tondi-san-van-hoa-viet-nam-330691.html.

NHAN DAN ONLINE NEWS. Shortcomings in supporting folk artists. Available at: https://nhandan.com. $\mathrm{vn} /$ dong-chay/bat-cap-trong-dai-ngo-nghe-nhan-dangian-327225/.

O'KEEFE, Patrick J. Commentary on the 1970 UNESCO Convention. 2. ed. Builth Wells: The Institute of Art and Law, 2007.

PHÁT huy giá trị di sản văn hóa, tạo cơ hội phát triển du lịch [Promotion of cultural heritage values and creation of opportunities for tourism development]. Available at: http:/ / tuyengiao.vn/van-hoa-xa-hoi/van-hoa/ phat-huy-gia-tri-di-san-van-hoa-tao-co-hoi-phat-triendu-lich-125393.

TU, Thi Loan. Cultural heritage in Vietnam with the requirements of sustainable development. International Relations and Diplomacy, v. 7, n. 4, p. 172-187.

UNESCO. Convention Concerning the Protection of the World Cultural and Natural Heritage. 1972.

UNESCO. Convention for the Safeguarding of Intangible Cultural Heritage. 2003.
UNESCO. Convention on the Means of Probibiting and Preventing the Illicit Import, Export and Transfer of Ownership of Cultural Property. 1970.

UNESCO. Convention on the Protection and Promotion of the Diversity of Cultural Expression. 2005.

UNESCO. General Conference Resolution 27. UNESCO 30th session. Paris, 26 Oct.-17 Nov. 1999. Available at: https://unesdoc.unesco.org/ark:/48223/ pf0000118514.

UNESCO. States Parties. Ratification Status of Vietnam. The Convention on the Protection and Promotion of the Convention on the Means of Probibiting and Preventing the Illicit Import, Export and Transfer of Ownership of Cultural Property. 1970. Available at: https://pax.unesco.org/la/convention. asp?order $=$ alpha\&language $=\mathrm{E} \& \mathrm{KO}=13039$.

UNESCO. States Parties. Ratification Status of Vietnam. The Convention on the Protection and Promotion of the Diversity of Cultural Expressions. 2005. Available at: https://pax.unesco.org/la/convention.asp? $\mathrm{KO}=31038$ \&language $=$ E\&order $=$ alpha .

UNESCO. States Parties. Ratification Status of Vietnam. The Convention for the Safeguarding of the Intangible Cultural Heritage. 2003. Available at: https://pax.unesco. org $/$ la $/$ convention.asp? $\mathrm{KO}=17116 \&$ language $=\mathrm{E} \&$ ord er=alpha.

UNESCO. States Parties. Ratification Status of Vietnam. The Convention Concerning the Protection of the World Cultural and Natural Heritage. 1972. Vietnam ratified the 1972 World Heritage Convention on 19 October 1987. Available at: https://whc.unesco.org/en/statesparties/.

UNESCO. Statutes of the Intergovernmental Committee for Promoting the Return of Cultural Property to its Countries of Origin or its Restitution in case of Illicit Appropriation. 20 C/ Resolution 4/7.6/5 of the 20th session of the General Conference of UNESCO. Paris, 24 Oct.-28 Nov. 1978. Available at: https://unesdoc.unesco.org/ark:/48223/ pf0000145960.

UNESCO. UNESCO Constitution. 1945.

UNESCO. World Heritage Committee. Final periodic report: state of the world heritage in Asia and the Pacific. 2003 synthesis periodic report for the Asia-Pacific region. WHC-03/27.COM/6A. Paris, 16 June 2003. Available at: https://whc.unesco.org/archive/2003/whc0327com-06ae.pdf. 
UNESCO. World Heritage Committee. Final report on the results of the second cycle of the Period Reporting exercise for Asia and the Pacific. WHC-12/36.COM/10A. Paris, 01 June 2012. Available at: https://whc.unesco.org/archive/2012/whc12-36com-10A-en.pdf.

UNITED NATIONS. Charter of the United Nations. 1945.

UNITED NATIONS. Vienna Convention on the Law of Treaties. Vienna, 23 May 1969. Treaty series, v. 1155, p. 331. Available at: https://treaties.un.org/ Pages $/$ ViewDetailsIII.aspx?src $=$ TREATY\&mtdsg no $=$ XXIII-1\&chapter $=23 \&$ Temp $=$ mtdsg $3 \&$ clang $=$ en.

VIETNAM. [Constitution (2013)]. Constitution of the Socialist Republic of Vietnam.

VIETNAM. Law No. 16/2017/QH14 dated 15 November 2017. Forestry of the Socialist Republic of Vietnam.

VIETNAM. Law No. 28/2001/QH10 dated 23 July 2013. Cultural Heritage of the Socialist Republic of Vietnam. Available at: https://sherloc.unodc.org/res/cld/document/vnm/law-on-cultural-heritage_html/vn_law_cltal_heritage_engtof.pdf.
VIETNAM. Law No. 50/2014/QH13 dated 18 June 2014. Construction of the Socialist Republic of Vietnam.

VIETNAM. Law No. 55/2014/QH13 dated 23 June 2014. Environmental Protection of the Socialist Republic of Vietnam.

WORLD BANK GROUP. Vibrant Vietnam: forging the foundation of a high-income economy: main report. May 2020. Available at: https://documents.worldbank. org/curated/en/745271590429811414/pdf/Main-Report.pdf.

XỬ lý hiệu quả hành vi vi phạm di sản quốc gia [Effective dealing with violations against national heritage properties]. Available at: https://nhandan.com.vn/ di-san/xu-ly-hieu-qua-hanh-vi-xam-pham-di-san-quocgia-375905/. 
Para publicar na Revista de Direito Internacional, acesse o endereço eletrônico www.rdi.uniceub.br ou www.brazilianjournal.org.

Observe as normas de publicação, para facilitar e agilizar o trabalho de edição. 